\title{
Interaction of unsaturated fat or coconut oil with monensin in lactating dairy cows fed 12 times daily. I. Protozoal abundance, nutrient digestibility, and microbial protein flow to the omasum ${ }^{1}$
}

\author{
C. Reveneau, ${ }^{*} \dagger$ S. K. R. Karnati, $\dagger^{2}$ E. R. Oelker, $\dagger$ and J. L. Firkins $\dagger^{3}$ \\ ${ }^{*}$ Ohio State University Interdisciplinary Nutrition Program (OSUN) and \\ †Department of Animal Sciences, The Ohio State University, Columbus 43210
}

\begin{abstract}
Monensin (tradename: Rumensin) should reduce the extent of amino acid deamination in the rumen, and supplemental fat should decrease protozoal abundance and intraruminal $\mathrm{N}$ recycling. Because animal-vegetable (AV) fat can be biohydrogenated in the rumen and decrease its effectiveness as an anti-protozoal agent, we included diets supplemented with coconut oil (CNO) to inhibit protozoa. In a $6 \times 6$ Latin square design with a $2 \times 3$ factorial arrangement of treatments, 6 rumen-cannulated cows were fed diets without or with Rumensin $(12 \mathrm{~g} / 909 \mathrm{~kg})$ and either no fat (control), $5 \%$ AV fat, or $5 \%$ CNO. The $\log 10$ concentrations (cells $/ \mathrm{mL}$ ) of total protozoa were not different between control (5.97) and AV fat (5.95) but were decreased by CNO (4.79; main effect of fat source). Entodinium and Dasytricha decreased as a proportion of total cells from feeding CNO, whereas Epidinium was unchanged in total abundance and thus increased proportionately. Total volatile fatty acid concentration was not affected by diet, but the acetate:propionate ratio decreased for CNO (1.85) versus control (2.95) or AV fat (2.58). Feeding CNO (23.8\%) decreased ruminal neutral detergent fiber digestibility compared with control $(31.1 \%)$ and AV fat $(30.5 \%)$. The total-tract digestibility of NDF was lower for CNO (45.8\%) versus control (57.0\%) and AV fat (54.6\%), with no difference in apparent organic matter digestibility (averaging 69.8\%). The omasal flows of microbial $\mathrm{N}$ and non-ammonia $\mathrm{N}$ were lower for CNO versus control and AV fat, but efficiency of microbial protein synthesis was not affected. The dry matter

\footnotetext{
Received August 30, 2011.

Accepted November 19, 2011.

${ }^{1}$ Research was supported by state and federal funds appropriated to the Ohio Agricultural Research and Development Center, The Ohio State University. Manuscript number 12/11AS. Additional funds provided by the US Department of Agriculture Cooperative State Research, Education, and Extension Service USDA/NRICGP Grant 2003-35206-12872 and Elanco Animal Health, Greenfield, IN.

${ }^{2}$ Current address: Procter and Gamble, 8700 Mason-Montgomery Rd., Mason, OH 45040.

${ }^{3}$ Corresponding author: firkins.1@osu.edu
}

intake was $4.5 \mathrm{~kg} / \mathrm{d}$ lower with $\mathrm{CNO}$, which decreased milk production by $3.1 \mathrm{~kg} / \mathrm{d}$. Main effect means of dry matter intake and milk yield tended to decrease by 0.7 and $1.2 \mathrm{~kg} / \mathrm{d}$, respectively, when Rumensin was added. Both percentage and production of milk fat decreased for CNO (main effect of fat source). An interaction was observed such that AV decreased milk fat yield more when combined with Rumensin. Using large amounts of supplemental fat, especially CNO, to decrease abundance of protozoa requires further research to characterize benefits versus risks, especiallywhen combined with Rumensin.

Key words: rumen protozoa, dietary fat, biohydrogenation, fiber digestibility

\section{INTRODUCTION}

Microbial protein is the major source of metabolizable protein for dairy cows (NRC, 2001); the capture of feed $\mathrm{N}$ as microbial $\mathrm{N}$, therefore, is an important factor to prevent the excess formation of ruminal ammonia, leading to urea synthesis and excretion in the urine (Hristov and Jouany, 2005). One important way to improve the capture of dietary $\mathrm{N}$ is to decrease protein degradation and amino acid deamination relative to the amount of microbial protein flowing to the duodenum, potentially mediated through suppressing protozoal abundance (Firkins et al., 2007) or defaunation. However, methods for complete defaunation usually carry longer-term residual effects (Hristov and Jouany, 2005) and are not practical for farm applications.

Supplemental dietary lipids have been researched to decrease protozoal abundance in the rumen (Doreau and Ferlay, 1995). Animal-vegetable (AV) fat can provide monounsaturated and PUFA in dairy diets. However, the response to AV fat supplementation on protozoal numbers is not consistent, possibly because of biohydrogenation (BH) of PUFA to decrease the potential inhibitory effects on rumen protozoa (Oldick and Firkins, 2000). Consequently, more research is needed to understand how PUFA affect protozoal metabolism to more reliably decrease protozoal numbers 
without the counter risk imposed by PUFA-mediated depression in fiber digestibility or milk fat depression (Firkins et al., 2008).

Medium-chain FA (MCFA) have been used to consistently decrease protozoal abundance (Machmüller and Kreuzer, 1999; Hristov et al., 2004c). Hristov et al. (2004b) dosed $240 \mathrm{~g}$ of sodium laurate once daily into the rumen of dairy cows, and this amount did not depress DMI but greatly decreased total counts of ruminal protozoa; however, greater amounts of sodium laurate $(480 \mathrm{~g} / \mathrm{d})$ did compromise DMI. The $240 \mathrm{~g} / \mathrm{d}$ dosage did not depress DMI in one subsequent study (Hristov et al., 2009) but depressed it by over $5 \mathrm{~kg} / \mathrm{d}$ in another (Hristov et al., 2011). The latter study did help document the efficacy for lauric acid to decrease protozoal counts compared with myristic or stearic acids. Although dosing via the rumen cannula concentrates the dose to decrease protozoal counts and rules out palatability issues (Hristov et al., 2009, 2011), more research is needed to establish the effects of coconut oil (CNO) fed to dairy cows to provide lauric acid compared with sources of PUFA on protozoal abundance, DMI, and nutrient digestibility.

We reasoned that differences in palatability and meal feeding pattern for cows fed fat can promote variability in supplemental fat bioactivity among trials. Oldick and Firkins (2000) demonstrated that ruminal protozoal abundance decreased linearly with increasing unsaturation of fat in dairy heifers fed $4.85 \%$ supplemental dietary fat. Those authors suggested that a more continuous meal pattern would allow $\mathrm{BH}$ to maintain an effective dose of PUFA below the toxicity threshold, and we questioned if increasing feeding frequency would lessen potential negative effects of AV fat or CNO on digestibility or DMI. We reasoned in the current study that an inclusion of at least $5 \%$ fat would be necessary to compare the effects of $\mathrm{AV}$ fat versus CNO (approximately $45 \%$ lauric acid) on fermentation, $\mathrm{BH}$, and protozoal abundance in dairy cows fed every 2 $\mathrm{h}$ to control for variable meal feeding behavior.

Commercialized under the tradename Rumensin $(\mathbf{R})$, monensin improves feed efficiency, in part through inhibiting bacteria responsible for extensive proteolysis and deamination (McGuffey et al., 2001; Ipharraguerre and Clark, 2003). Rumensin decreased ruminal $\mathrm{NH}_{3}-\mathrm{N}$ concentration (Ruiz et al., 2001), apparently mediated through decreased proteolysis (Yang and Russell, 1993). Using ${ }^{15} \mathrm{~N}$, Hristov et al. (2009) reported that CNO decreased ruminal $\mathrm{NH}_{3}-\mathrm{N}$ flux rate. Thus, we hypothesized that the combination of $\mathrm{R}$ plus fat, especially for CNO versus AV fat, would improve efficiency of microbial protein synthesis (EMPS) and dietary N capture as microbial protein. Our objectives were to evaluate the feeding of $\mathrm{AV}$ fat or $\mathrm{CNO}$ without or with
$\mathrm{R}$ on protozoal abundance, ruminal fermentation, omasal flow, total-tract digestibility, and milk production.

\section{MATERIALS AND METHODS}

\section{Animals and Diets}

Six primiparous Holstein cows were fitted with rumen cannulas and used per the approved guidelines of The Ohio State University Institutional Animal Care and Use Committee. At the start of the experiment, cows were 48, 64, 87, 88, 94, and 95 DIM. All 6 cows received each of the 6 diets in 6 periods in a $6 \times 6$ Latin square design. Experimental periods consisted of $21 \mathrm{~d}$; d 1 through 14 served as an adjustment period, and d 15 to 21 were for data collection, except for the initial period of $4 \mathrm{wk}$ for acclimatization to $\mathrm{R}$. A dosage rate of $12 \mathrm{~g} / 909 \mathrm{~kg}$ of $\mathrm{R}$ of the total TMR on a DM basis was supplemented to be slightly higher than the label rate of $11 \mathrm{~g} / 909 \mathrm{~kg}$ to provide a safety factor against lower inclusion rate. For periods 2 through $6,20 \mathrm{~kg}$ of ruminal contents from the cows rotating off each treatment were transferred to subsequent animals rotating on those respective treatments to facilitate adaptation to R. Cows were injected with Posilac (Elanco Animal Health, Greenfield, IN) 2 wk before the initiation of the feeding trial and every $2 \mathrm{wk}$ throughout the trial. Cows were weighed before the p.m. milking on d 21 of each period. One cow was not used for data collection during period 2 (CNO treatment) because of environmental mastitis, which was resolved before the following period.

The dietary treatments were arranged in a $2 \times 3$ factorial without or with $\mathrm{R}$ and either no supplemental fat, $5.0 \%$ AV fat, or 5.0\% CNO. All 6 diets were formulated to have $42 \%$ NFC, $16.8 \% \mathrm{CP}$, and $49 \%$ forage, which consisted of alfalfa hay:corn silage (33:67 DM basis) to provide $21.5 \%$ forage NDF (Table 1 ). The alfalfa hay was chopped before mixing. Composited samples of TMR were sieved using the Penn State Particle Separator (pore sizes of 19.0, 8.0, and $1.18 \mathrm{~mm}$; University Park). Geometric mean particle length (based on a lognormal distribution) was $5.2 \pm 1.6 \mathrm{~mm}$. Calcium and $\mathrm{Mg}$ were supplemented at 1.0 and $0.30 \%$, respectively, of DM in all diets because of the high fat inclusion; all other minerals were formulated to meet NRC (2001) guidelines.

Cows were housed in a conventional tie-stall barn with mattresses. They were fed one-twelfth of their daily feed allowance every $2 \mathrm{~h}$ using automatic feeders (ANKOM Technology, Macedon, NY). Cows were fed for $10 \%$ orts for the first week, and feed offered was adjusted to ensure $2 \%$ orts during the second week and then to $<1 \%$ orts during the collection week to help 
Table 1. Ingredient compositon of diets without or with Rumensin (R) and without or with $5 \%$ fat from animal-vegetable (AV) fat or coconut oil $(\mathrm{CNO})$

\begin{tabular}{|c|c|c|c|c|c|c|}
\hline \multirow{2}{*}{ Item $(\%$ of DM) } & \multicolumn{6}{|c|}{ Diet $^{1}$} \\
\hline & \multicolumn{3}{|c|}{$-\mathrm{R}$} & \multicolumn{3}{|c|}{$+\mathrm{R}$} \\
\hline Alfalfa hay, chopped & 16.2 & 16.2 & 16.2 & 16.2 & 16.2 & 16.2 \\
\hline Corn silage & 32.8 & 32.8 & 32.8 & 32.8 & 32.8 & 32.8 \\
\hline Corn, ground shelled & 23.3 & 25.1 & 25.1 & 23.3 & 25.1 & 25.1 \\
\hline SoyPLUS $^{2}$ & 3.10 & 3.20 & 3.20 & 3.10 & 3.20 & 3.20 \\
\hline AV fat & - & 5.00 & - & - & 5.00 & - \\
\hline $\mathrm{CNO}^{3}$ & - & - & 5.00 & - & - & 5.00 \\
\hline Urea & 0.150 & 0.150 & 0.150 & 0.150 & 0.150 & 0.150 \\
\hline Dicalcium phosphate & 0.275 & 0.275 & 0.275 & 0.275 & 0.275 & 0.275 \\
\hline Limestone & 1.200 & 1.200 & 1.200 & 1.200 & 1.200 & 1.200 \\
\hline Magnesium oxide & 0.150 & 0.150 & 0.150 & 0.150 & 0.150 & 0.150 \\
\hline
\end{tabular}

${ }^{1}$ Rumensin supplementation (12 g/909 kg of DM); AV fat: $5.0 \%$ added AV blend; CNO: $5.0 \%$ added CNO.

${ }^{2}$ West Central Soy, Ralston, IA.

${ }^{3}$ Cereal By-Products, Mt. Prospect, IL.

${ }^{4}$ Contained $0.10 \% \mathrm{Mg}, 38.0 \% \mathrm{Na}, 58.0 \% \mathrm{Cl}, 0.04 \% \mathrm{~S}$, and $(\mathrm{mg} / \mathrm{kg}) \mathrm{Fe}, 5,000 ; \mathrm{Zn}, 7,500 ; \mathrm{Cu}, 2,500 ; \mathrm{Mn}, 6,000 ; \mathrm{I}, 100 ; \mathrm{Se}, 60 ;$ and Co, 50.

${ }^{5}$ Supplied approximately $100 \mathrm{kIU}$ of vitamin A, $35 \mathrm{kIU}$ of vitamin D, and $700 \mathrm{IU}$ of vitamin E/cow per day.

${ }^{6}$ Supplied 80 g/454 g (Elanco Animal Health, Indianapolis, IN).

sequence their eating with the 2-h feedings. Orts were measured at $1600 \mathrm{~h}$ daily, diets were hand-mixed as a TMR, and fresh feed was offered beginning at $1800 \mathrm{~h}$ daily. Adjustments to the as-fed TMR were made on a weekly basis based on the DM percentage of corn silage and other feeds.

Cows were milked at 0500 and $1700 \mathrm{~h}$ daily. Four consecutive milk samples were taken on d 17 to 19 of each period, and each sample was divided into 2 aliquots. The first aliquot of the milk sample was stored at $4^{\circ} \mathrm{C}$ with a preservative and analyzed by DHI Cooperative Inc. (Columbus, OH) for milk fat, true protein, and lactose content by infrared spectroscopy and for MUN content using a Skalar SAN Plus segmented flow analyzer (Skalar Inc., Norcross, GA). Milk components were mathematically weighted for milk weights per milking. Data were averaged per period before statistical analysis. The second milk aliquot was frozen at $-20^{\circ} \mathrm{C}$ for $\mathrm{FA}$ analysis.

\section{Feed Sampling and Analysis}

Feed offered and individual dietary components were sampled on d 13 through 15, and orts were sampled on d 14 through 16 of the collection period and stored at $-20^{\circ} \mathrm{C}$. A composite of each sample was dried at $60^{\circ} \mathrm{C}$ and ground in a Wiley mill (Arthur H. Thomas
Co., Philadelphia, PA) through a 2-mm screen before nutrient analyses. The feed offered, orts, and individual components were analyzed for DM, OM, and Kjeldahl $\mathrm{N}$ concentration (AOAC, 1990). Fatty acid analysis was conducted with one of the procedures reviewed by Palmquist and Jenkins (2003) as modified by Mathew et al. (2011) and outlined in more detail in Reveneau et al. (2012).

The feed, orts, and digesta were analyzed for NDF using a fiber analyzer (ANKOM A200, ANKOM Technology). Half-gram samples were thermally sealed in filter bags, presoaked in acetone, and refluxed for $75 \mathrm{~min}$ in the presence of FAA heat-stable amylase (ANKOM Technology) plus $20 \mathrm{~g}$ of $\mathrm{Na}_{2} \mathrm{SO}_{3}$. A procedure similar to that for NDF (including acetone presoak and use of $\mathrm{Na}_{2} \mathrm{SO}_{3}$ ) was used to analyze ADF using the ANKOM filter bag method, followed by lignin analyses according to AOAC (1990). Residues from these steps were subjected to Kjeldahl analysis of $\mathrm{N} \times 6.25$ to determine dietary NFC without double counting CP. However, analyses were repeated without using $\mathrm{Na}_{2} \mathrm{SO}_{3}$ to assay neutral and acid detergent-insoluble CP separately. Samples of TMR composited over the collection phase of each period were applied to the Penn State Particle Size Separator, as detailed by the manufacturer except that results were on a $55^{\circ} \mathrm{C}$ basis. The dried and ground TMR samples were digested in perchloric acid 
before mineral analyses by inductively coupled plasma emission spectroscopy by the Ohio State University Service Testing and Research Lab (STAR) laboratory (Wooster).

\section{Ruminal Evacuation}

The complete evacuation of ruminal contents was performed on d 20 at $0800 \mathrm{~h}$ and on d 21 at $1200 \mathrm{~h}$ of each period, with solid and liquid fractions separated using a hydraulic wine press $\left(17\right.$ Newtons $\left./ \mathrm{cm}^{2}\right)$. The $\mathrm{pH}$ of the fluid was measured immediately using a portable $\mathrm{pH}$ meter. After weighing and sampling each fraction, ruminal contents were returned to the cow within 25 min. A subsample was reconstituted proportionately to the liquid and solid weights for subsequent analyses.

The liquid fraction from the evacuation subsamples was partitioned into aliquots for determination of protozoal counts, VFA, $\mathrm{NH}_{3}-\mathrm{N}$, and DM contents. For protozoal counts, a $25-\mathrm{mL}$ aliquot of the ruminal fluid was mixed 1:2 with 50\% formalin solution (vol/vol) and counted (Dehority, 1993). A 47-mL aliquot of the ruminal fluid was acidified with $3 \mathrm{~mL}$ of $6 \mathrm{~N} \mathrm{HCl}$ to stop fermentation before freezing. The ruminal fluid was later thawed, mixed, and centrifuged at 15,000 $\times g$ at $4^{\circ} \mathrm{C}$ for $15 \mathrm{~min}$ and then filtered through Whatman number 1 filter paper (Whatman Inc., Clifton, NJ). The supernatant was analyzed for VFA concentrations by GLC (Harvatine et al., 2002).

The solid fraction from the evacuation was split into 2 subsamples; the first one was used for DM and dried at $55^{\circ} \mathrm{C}$ in a forced-air oven, and the second was used for solid-associated bacteria (SAB) fractionation. After washing a $200-\mathrm{g}$ sample with $0.9 \%$ saline (wt/vol), the sample was frozen in $100 \mathrm{~mL}$ of distilled $\mathrm{H}_{2} \mathrm{O}$ that had been acidified with $\mathrm{HCl}$ to $\mathrm{pH} 2.0$ to extract $\mathrm{SAB}$ (Whitehouse et al., 1994). Samples were later thawed, and SAB was extracted by blending the samples for 30 min in $250 \mathrm{~mL}$ of cold $0.9 \%$ saline (wt/vol) twice. After filtering through 2 layers of cheesecloth, the sample was then centrifuged at $500 \times g$ for 15 min at $4^{\circ} \mathrm{C}$ to remove feed particles; the supernatant was further spun to $12,000 \times g$ for $15 \mathrm{~min}$, washed with cold distilled $\mathrm{H}_{2} \mathrm{O}$, spun again, frozen, and subsequently freeze-dried for further analysis.

\section{Flow Marker Administration}

Because $\mathrm{Yb}$ tends to preferentially bind to small particles with high surface area, we intended to remove small particles before the marking process. Corn silage was dried at $55^{\circ} \mathrm{C}$ in a forced-air oven and separated on the Pennsylvania State Particle Size Separator. Particles larger than $8 \mathrm{~mm}$ were ground through a 5-mm screen using a Wiley Mill. The fractions were then combined and separated manually on a $1.18-\mathrm{mm}$ sieve with circular and vertical pulsating motion; the particles passing through the sieve were discarded. The particles of corn silage $\geq 1.18 \mathrm{~mm}$ were labeled with $\mathrm{YbCl}_{3}$ according to Hristov and Broderick (1996), with the following changes: the forage was soaked in distilled $\mathrm{H}_{2} \mathrm{O}$ at $23^{\circ} \mathrm{C}$ for $24 \mathrm{~h}$ to remove soluble DM, washed with tap water, and squeezed through 8 layers of cheesecloth. The forage was then soaked for $48 \mathrm{~h}$ at room temperature in distilled $\mathrm{H}_{2} \mathrm{O}(5 \mathrm{~L} / \mathrm{kg}$ of forage) mixed with $\mathrm{YbCl}_{3} \cdot 6 \mathrm{H}_{2} \mathrm{O}$ (5\% wt/wt of forage $\left.\mathrm{DM}\right)$ for the first batch. Availability by the manufacturer caused us to decrease dosage to approximately $1.8 \%$ (wt/wt). After washing the forage with tap water and squeezing through cheesecloth, the forage was soaked in approximately $0.1 N$ acetic acid solution (enough to maintain $\mathrm{pH} 4.5$ to 5.0) to displace $\mathrm{Yb}$ that was bound to lowaffinity sites. The labeled forage was subsequently washed with tap water, squeezed through cheesecloth, dried at $55^{\circ} \mathrm{C}$ in a forced-air oven, and split into small doses. Labeled corn silage was prepared 3 times, with an efficiency of labeling of approximately $50 \%$. The 3 doses contained 1.61 (first period), 0.604 (periods 2 and 3 ), and 0.589 (periods 4 to 6 ) $\mathrm{g}$ of $\mathrm{Yb} / 100 \mathrm{~g}$ of corn silage DM. The dose was set at $20 \mathrm{~g}$ of Yb-labeled corn silage dosed via the rumen cannula between $\mathrm{d} 11$ and 18 at 0700,1500 , and $2300 \mathrm{~h}$, followed by manual mixing.

Cobalt-EDTA was prepared as described previously by Uden et al. (1980). The Co-EDTA (1.2 g) was diluted into $100 \mathrm{~mL}$ of distilled $\mathrm{H}_{2} 0$ and dosed via the rumen cannula 3 times per day. For use as a microbial marker, $1.6 \mathrm{~g}$ of $\left({ }^{15} \mathrm{NH}_{4}\right)_{2} \mathrm{SO}_{4}$ (10 atom \%; Isotec Inc., Miamisburg, $\mathrm{OH}$ ) was dosed 3 times per day along with the Co-EDTA and at the same times as the Yb-labeled corn silage. Background samples for markers were taken from the rumen each period on $\mathrm{d} 10$.

\section{Omasal and Ruminal Sampling}

Although omasal flow values presented later are based on whole digesta (see later discussion), our original intention was to use the double-marker method to reconstitute liquid and solids fractions for measurement of omasal flow. Using the method of omasal sampling described by Huhtanen et al. (1997) and modified later (Ahvenjärvi et al., 2001), digesta was collected from the omasal canal via a tube passing through the rumen cannula attached to a machine reciprocating positive and negative pressure. On d 14 to 16, $500 \mathrm{~mL}$ of each digesta sample was taken every $2 \mathrm{~h}$ at 4 times, with an 8 -h shift per day of the sampling times so that sampling was done every $2 \mathrm{~h}$ over a 24 -h schedule. A $200-\mathrm{mL}$ aliquot 
was kept as whole omasal digesta; the 12 samples of whole digesta over the $3 \mathrm{~d}$ were later combined, mixed, and split into 3 subsamples and frozen at $-20^{\circ} \mathrm{C}$. A 50-mL aliquot for non- $\mathrm{NH}_{3}-\mathrm{N}$ was combined with $2 \mathrm{~mL}$ of $2 \mathrm{~N} \mathrm{NaOH}$ to bring the pH up to 9; the 12 samples over the $3 \mathrm{~d}$ were later combined, mixed, and split into 2 subsamples, frozen at $-20^{\circ} \mathrm{C}$, and later dried at $55^{\circ} \mathrm{C}$ in a forced-air oven to evolve $\mathrm{NH}_{3}$. The other $250-\mathrm{mL}$ aliquot was separated into solid and liquid fractions by squeezing through 4 layers of cheesecloth. A 94-mL aliquot was acidified with $6 \mathrm{~mL}$ of $6 \mathrm{~N} \mathrm{HCl}$ to stop fermentation; the 12 samples of acidified omasal fluid over the $3 \mathrm{~d}$ were later combined, mixed, and split into 4 subsamples, which were frozen at $-20^{\circ} \mathrm{C}$. The remaining liquid sample was fixed in $1 \%$ formalin solution to prevent cell lysis and kept at $4^{\circ} \mathrm{C}$. The solid was split into 2 subsamples: 1 for solids digesta and 1 for SAB. The 12 samples over the $3 \mathrm{~d}$ of sampling were combined per animal within period, respectively; the solid sample was dried at $55^{\circ} \mathrm{C}$ in a forced-air oven, and the $\mathrm{SAB}$ sample was processed as described above.

Passage rates from the rumen were measured on $\mathrm{d}$ 18 and 19. The Yb-marked corn silage, Co-EDTA and ${ }^{15} \mathrm{~N}$ were last dosed on $\mathrm{d} 18$ at $0700 \mathrm{~h}$, and ruminal samples were taken from 6 sites from the rumen at 0 (immediately before the last dose), and 0.33, 0.66, 1, 2, $3,4.5,6,8,14,20,26,29$, and $32 \mathrm{~h}$ thereafter. Samples were separated into solids and liquid as described for rumen evacuation before analysis of $\mathrm{Yb}$ and $\mathrm{Co}$.

\section{Rumen and Omsasal Flow Marker Measurements}

Solid ruminal samples, whole omasal digesta samples, and Yb-labeled corn silage doses were analyzed for $\mathrm{Yb}$ at the Virginia Tech Soil Testing Laboratory (Blacksburg, VA) with a Thermo Elemental Inductively Coupled Argon Plasma Atomic Emission Simultaneous Spectrometer (ICAP 61E; Thermo Fisher Scientific, Waltham, MA) using Thermo's ICP Manager 61 software equipped with a TJA-300 autosampler at a 328.937-nm wavelength. A 2-g sample was weighed, ashed at $450^{\circ} \mathrm{C}$ for $48 \mathrm{~h}$, and mixed with $10 \mathrm{~mL}$ of an acid solution $\left(3 \mathrm{~N} \mathrm{HCl}+3 \mathrm{NHNO}_{3}+1.91 \mathrm{~g}\right.$ of $\left.\mathrm{KCl} / \mathrm{L}\right)$. After $6 \mathrm{~h}$ of incubation, samples were vortexed and incubated overnight. Samples were then filtered through Whatman number 1 filter paper, and the filtrate was used to determine $\mathrm{Yb}$ concentration. After centrifugation at $20,000 \times g$ for $20 \mathrm{~min}$, the supernatant from liquid ruminal samples, omasal samples, and Co-EDTA doses were analyzed for Co concentration using atomic absorption spectrophotometry. The ${ }^{15} \mathrm{~N}$ analyses were conducted at the Department of Animal and Veterinary Sciences at the University of Idaho (Moscow) using isotope-ratio mass spectrometry. All $\mathrm{Yb}, \mathrm{Co}$, and ${ }^{15} \mathrm{~N}$ analyses were corrected for background (d 10). Because the $\mathrm{Co}$ and $\mathrm{Yb}$ data tended to increase after the dose followed by subsequent decline, the time points before 2 $\mathrm{h}$ were assumed to represent a distribution phase. Data from 2 to $32 \mathrm{~h}$ were fit to a mono-exponential curve using the NLIN procedure of SAS (v9.1; SAS Institute Inc., Cary, NC).

\section{Total-Tract Digestibility}

Digestibility was measured on d 14 to 16 of each period. A pellet containing 10\% chromic oxide and $90 \%$ soybean hulls was dosed through the rumen cannula 3 times per day on d 9 through 16 for a combined daily total of $1 \%$ of DMI. Fecal grab samples were taken on d 8 for background and d 14 to 16 of each period to represent every $4 \mathrm{~h}$ in a $24-\mathrm{h}$ period. Samples were dried in a forced-air oven at $55^{\circ} \mathrm{C}$ for $60 \mathrm{~h}$ and were composited for each animal by equal sample weight at the end of each period. The chromic oxide pellets were composited by period and ground manually using a mortar and pestle. Chromic oxide pellets and fecal samples were analyzed for Cr by atomic absorption spectroscopy (Williams et al., 1962). The samples of fecal contents were ground and analyzed for DM, OM, N, FA, and NDF content as described above.

\section{Statistical Analysis}

Ruminal protozoal counts, VFA concentration and pool size, nutrient digestibilities, and milk production and composition data were analyzed as a $6 \times 6$ Latin square for a $2 \times 3$ factorial arrangement of treatments using PROC MIXED of SAS (v9.1; SAS Institute Inc.) according to the following model: $Y_{i j k}=\mu+T_{i}+P_{j}+$ $c_{k}+e_{i j k}$, where $Y_{i j k}=$ the dependent variable, $\mu=$ overall mean, $T_{i}=$ the fixed effect of the $i$ th treatment $(i=1, \ldots, 6), P_{j}=$ the fixed effect of the $j$ th period $(j$ $=1, \ldots, 6), c_{k}=$ the random effect of the $k$ th cow $(k$ $=1, \ldots, 6)$, and $e_{i j k}=$ the random residual. All random effects were considered $\sim \mathrm{N}\left(0, \sigma_{\mathrm{e}}^{2}\right)$. Significant differences were declared at $P<0.05$ for main effects and $P<0.10$ for trends of main effects or for interactions. Treatment means were compared using 5 preplanned orthogonal contrasts, with 6 coefficients shown in brackets respectively for control, $\mathrm{AV}$ fat, $\mathrm{CNO}$, control $+\mathrm{R}, \mathrm{AV}$ fat + $\mathrm{R}$, and $\mathrm{CNO}+\mathrm{R}: 1$ ) the main effect of $\mathrm{R}\left[\begin{array}{llll}1 & 1 & 1 & -1\end{array}-1\right.$ $-1], 2)$ the main effect of control versus fat (i.e., the average of $\mathrm{AV}$ fat and $\mathrm{CNO})\left[\begin{array}{llllll}-2 & 1 & 1 & -2 & 1 & 1\end{array}\right]$, 3) the main effect of the fat source (i.e., AV fat vs. CNO) $[0$ $\left.\begin{array}{lllll}-1 & 1 & 0 & -1 & 1\end{array}\right]$, 4) the interaction between $\mathrm{R}$ and fat $\left[\begin{array}{llllll}-2 & 1 & 1 & 2 & -1 & -1\end{array}\right]$, and 5 ) the interaction between $\mathrm{R}$ and the fat source $\left[\begin{array}{llllll}0 & -1 & 1 & 0 & 1 & -1\end{array}\right]$. 


\section{RESULTS}

\section{Diet Composition}

The analyzed composition of the diets is shown in Table 2. Alfalfa averaged 20.0, 33.1, and $40.7 \%$ CP, $\mathrm{ADF}$, and NDF; corn silage averaged 8.9, 28.1, and $44.7 \%$, respectively. The nutrient composition of the total diet was close to the target formulations for NFC, $\mathrm{CP}$ and NDF. By design, the FA percentages of the fat-supplemented diets were, on average, 4.6 percentage units higher than that of the control diets. The dosage rate of monensin $(12 \mathrm{~g} / 909 \mathrm{~kg}$ of DM of the total diet) was confirmed by laboratory analysis (Elanco Animal Health; data not shown).

\section{Protozoal Abundance}

There was no effect of $\mathrm{R}$ on protozoal abundance (Table 3). The main effect means for fat $(\mathbf{F})$ were decreased compared with the control, primarily because of the main effect of fat source (S), with protozoal abundance being decreased by almost $1 \log$ unit or about $90 \%$ of actual counts for CNO compared with AV fat. When looking at specific protozoal profiles, the $\mathrm{R} \times$ fat interaction indicated that fat increased dividing forms (percentage of cells showing any stage of cell division) compared with the control without $\mathrm{R}$, but fat decreased the percentage of dividing cells compared with the control when $\mathrm{R}$ was added. When calculated as a percentage of total cells, Entodinium and Dasytricha species decreased with CNO. In contrast, Epidinium increased for the main effect of fat, which was caused by $\mathrm{CNO}$ (i.e., a main effect of S). Epidinium actual abundance was not affected by fat (data not shown), so the increased percentage responses were due to $\mathrm{CNO}$ inhibition of the other genera. Rumensin tended $(P=$ $0.10)$ to decrease Ophryoscolex, and fat source interactions with $\mathrm{R}$ resulted when Diplodinium and Isotricha decreased only when $\mathrm{CNO}$ was combined with R.

\section{Ruminal Fermentation}

No effects of treatment on ruminal $\mathrm{pH}$ were observed (Table 4). The addition of $\mathrm{R}$ did not affect total VFA concentration. However, total VFA concentration de-

Table 2. Analyzed composition for cows fed diets without or with Rumensin (R) and without or with $5 \%$ fat from animal-vegetable (AV) fat or coconut oil (CNO)

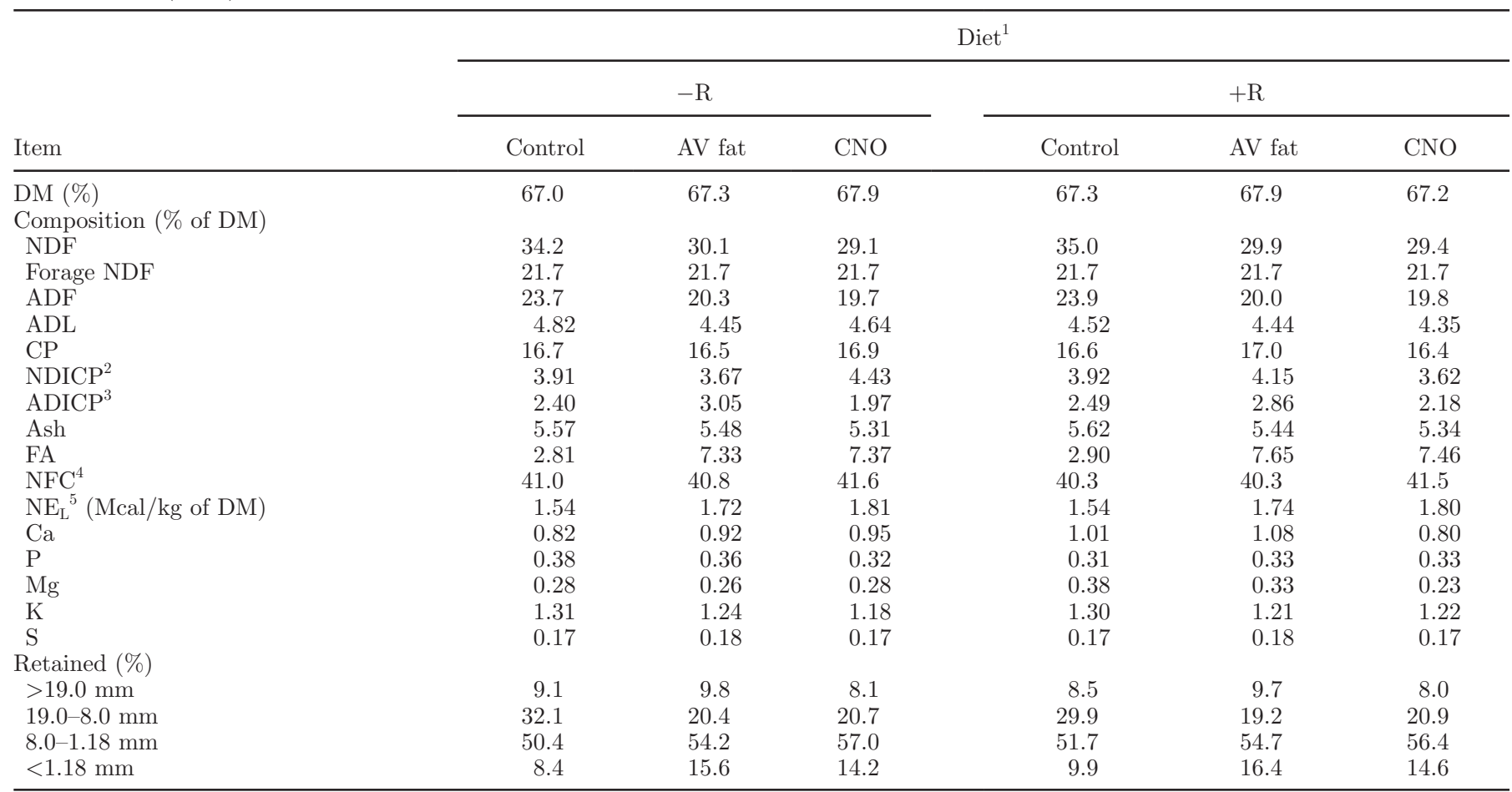

${ }^{1}$ Rumensin supplementation (12 g/909 kg of DM); AV fat: $5.0 \%$ added AV blend; CNO: $5.0 \%$ CNO.

${ }^{2}$ Neutral detergent insoluble CP from NDF prepared without sodium sulfite.

${ }^{3}$ Acid detergent insoluble CP was prepared without sodium sulfite.

${ }^{4}$ Nonfiber carbohydrates $\left[\mathrm{OM}-\mathrm{NDF}_{\mathrm{CP}-\text { free }}-\mathrm{CP}-(\mathrm{FA}+1)\right]$. The NDF was prepared using sodium sulfite and residual NDICP was subtracted in the NFC calculation.

${ }^{5}$ Net energy of lactation calculated from NRC (2001). 
Table 3. Least squares means for logarithm of protozoal concentration in ruminal fluid from cows fed diets without or with Rumensin (R) and without or with $5 \%$ fat from animal-

vegetable $(\mathrm{AV})$ fat or coconut oil $(\mathrm{CNO})$

\begin{tabular}{|c|c|c|c|c|c|c|c|c|c|c|c|c|}
\hline \multirow[b]{3}{*}{ Item } & \multicolumn{6}{|c|}{ Diet $^{1}$} & \multirow[b]{3}{*}{$\mathrm{SEM}^{2}$} & \multirow{2}{*}{\multicolumn{5}{|c|}{$P$-value ${ }^{3}$}} \\
\hline & \multicolumn{3}{|c|}{$-\mathrm{R}$} & \multicolumn{3}{|c|}{$+\mathrm{R}$} & & & & & & \\
\hline & Control & AV fat & $\mathrm{CNO}$ & Control & AV fat & $\mathrm{CNO}$ & & $\mathrm{R}$ & Fat & Source & $\mathrm{R} \times$ fat & $\mathrm{R} \times$ source \\
\hline $\begin{array}{l}\text { Total }\left(\log _{10}\right) \\
\% \text { of total }\end{array}$ & 5.91 & 5.86 & 4.86 & 6.01 & 5.98 & 4.74 & 0.12 & NS & $<0.01$ & $<0.01$ & NS & NS \\
\hline Dividing forms & 1.12 & 1.64 & 1.42 & 1.98 & 1.28 & 1.07 & 0.28 & NS & NS & NS & 0.02 & NS \\
\hline Entodinium & 86.6 & 86.4 & 68.0 & 90.1 & 89.1 & 69.0 & 6.6 & NS & 0.02 & $<0.01$ & NS & NS \\
\hline Epidinium & 7.80 & 9.26 & 25.5 & 5.43 & 5.18 & 29.6 & 5.90 & NS & 0.01 & $<0.01$ & NS & NS \\
\hline Diplodinium & 1.07 & 0.53 & 1.20 & 1.00 & 1.85 & 0.15 & 0.67 & NS & NS & NS & NS & 0.07 \\
\hline Ophryoscolex & 0.18 & 0.11 & $<0.01$ & 0.04 & $<0.01$ & $<0.01$ & 0.08 & 0.10 & 0.11 & NS & NS & NS \\
\hline Isotricha & 2.48 & 2.64 & 5.13 & 1.78 & 2.06 & 1.33 & 0.93 & 0.02 & NS & NS & NS & 0.08 \\
\hline Dasytricha & 1.88 & 1.08 & 0.14 & 1.62 & 1.79 & 0.10 & 0.37 & NS & $<0.01$ & $<0.01$ & NS & NS \\
\hline
\end{tabular}

${ }^{1}$ Rumensin supplementation (12 g/909 kg of DM); AV fat: $5.0 \%$ added AV blend; CNO: $5.0 \%$ added CNO.

${ }^{2}$ Standard error of the mean for $\mathrm{n}=6$.

${ }^{3}$ Probability of a treatment response; NS: $P>0.20$. Contrasts compared the main effect of $\mathrm{R}$ (diets without vs. with $\mathrm{R}$ averaged over fat treatments), the main effect of fat (Fat $=$ control vs. the average of the 2 fat diets averaged over $\mathrm{R}$ ), the main effect of source of fat (source $=$ AV fat vs. CNO averaged over $\mathrm{R}$ ), the interaction between $\mathrm{R}$ and fat $(\mathrm{R} \times$ fat), and the interaction between $\mathrm{R}$ and source of fat $(\mathrm{R} \times$ source). See Materials and Methods section for contrasts.

Table 4. Least squares means for ruminal fermentation characteristics for cows fed diets without or with Rumensin (R) and without or with $5 \%$ fat from animal-vegetable (AV) fat or coconut oil (CNO)

Diet $^{1}$

\begin{tabular}{|c|c|c|c|c|c|c|c|c|c|c|c|c|}
\hline \multirow[b]{3}{*}{ Item } & & \multirow[b]{3}{*}{$\mathrm{SEM}^{2}$} & \multirow{2}{*}{\multicolumn{5}{|c|}{$P$-value ${ }^{3}$}} \\
\hline & \multicolumn{3}{|c|}{$-\mathrm{R}$} & \multicolumn{3}{|c|}{$+\mathrm{R}$} & & & & & & \\
\hline & Control & AV fat & $\mathrm{CNO}$ & Control & AV fat & $\mathrm{CNO}$ & & $\mathrm{R}$ & Fat & Source & $\mathrm{R} \times$ fat & $\mathrm{R} \times$ source \\
\hline Ruminal pH & 5.94 & 5.81 & 5.91 & 5.97 & 6.02 & 5.86 & 0.09 & NS & NS & NS & NS & 0.17 \\
\hline Total VFA $(\mathrm{m} M)$ & 133 & 123 & 129 & 143 & 127 & 123 & 6 & NS & 0.02 & NS & NS & NS \\
\hline VFA $(\mathrm{mol} / 100 \mathrm{~mol})$ & & & & & & & & & & & & \\
\hline Acetate & 62.2 & 60.0 & 54.7 & 62.6 & 57.7 & 54.4 & 1.1 & NS & $<0.01$ & $<0.01$ & NS & NS \\
\hline Propionate & 21.5 & 23.4 & 30.2 & 21.4 & 24.4 & 30.6 & 1.3 & NS & $<0.01$ & $<0.01$ & NS & NS \\
\hline Butyrate & 12.4 & 12.7 & 10.5 & 12.0 & 13.6 & 10.9 & 0.8 & NS & NS & $<0.01$ & NS & NS \\
\hline Isobutyrate & 0.879 & 0.869 & 0.829 & 0.954 & 0.994 & 0.830 & 0.033 & 0.02 & NS & $<0.01$ & NS & 0.08 \\
\hline Isovalerate & 1.49 & 1.39 & 1.35 & 1.72 & 1.60 & 1.21 & 0.12 & NS & 0.05 & 0.18 & NS & 0.18 \\
\hline Valerate & 1.54 & 1.69 & 2.41 & 1.39 & 1.63 & 2.09 & 0.13 & 0.11 & $<0.01$ & $<0.01$ & NS & NS \\
\hline Acetate:propionate & 2.94 & 2.69 & 1.86 & 2.98 & 2.46 & 1.83 & 0.15 & NS & $<0.01$ & $<0.01$ & NS & NS \\
\hline Ruminal $\mathrm{NH}_{3}-\mathrm{N}(\mathrm{mg} / \mathrm{dL})$ & 10.8 & 11.8 & 10.5 & 9.8 & 11.4 & 9.9 & 1.1 & NS & NS & 0.16 & NS & NS \\
\hline
\end{tabular}

${ }^{1}$ Rumensin supplementation (12 g/909 kg of DM); AV fat: $5.0 \%$ added AV blend; CNO: $5.0 \%$ added CNO.

${ }^{2}$ Standard error of the mean for $\mathrm{n}=6$.

${ }^{3}$ Probability of a treatment response; NS: $P>0.20$. Contrasts compared the main effect of $\mathrm{R}$ (diets without vs. with $\mathrm{R}$ averaged over fat treatments), the main effect of fat (Fat $=$ control vs. the average of the 2 fat diets averaged over $\mathrm{R}$ ), the main effect of source of fat (source $=\mathrm{AV}$ fat vs. CNO averaged over $\mathrm{R}$ ), the interaction between $\mathrm{R}$ and fat $(\mathrm{R} \times$ fat), and the interaction between $\mathrm{R}$ and source of fat $(\mathrm{R} \times$ source). See Materials and Methods section for contrasts. 
Table 5. Least squares means for ruminal pool size and passage kinetics for cows fed diets without or with Rumensin (R) and without or with $5 \%$ fat from animal-vegetable (AV) fat or coconut oil (CNO)

\begin{tabular}{|c|c|c|c|c|c|c|c|c|c|c|c|c|}
\hline \multirow[b]{3}{*}{ Item } & \multicolumn{6}{|c|}{ Diet $^{1}$} & \multirow[b]{3}{*}{$\mathrm{SEM}^{2}$} & \multirow{2}{*}{\multicolumn{5}{|c|}{$P$-value ${ }^{3}$}} \\
\hline & \multicolumn{3}{|c|}{$-\mathrm{R}$} & \multicolumn{3}{|c|}{$+\mathrm{R}$} & & & & & & \\
\hline & Control & $\mathrm{AV}$ fat & $\mathrm{CNO}$ & Control & AV fat & $\mathrm{CNO}$ & & $\mathrm{R}$ & Fat & Source & $\mathrm{R} \times$ fat & $\mathrm{R} \times$ source \\
\hline Ruminal mass ${ }^{4}(\mathrm{~kg})$ & 72.7 & 65.8 & 70.1 & 68.3 & 57.9 & 67.9 & 2.7 & 0.01 & 0.01 & $<0.01$ & NS & NS \\
\hline Ruminal liquid $^{5}(\mathrm{~kg})$ & 39.7 & 34.6 & 35.5 & 36.3 & 30.1 & 38.6 & 2.3 & NS & 0.02 & $<0.01$ & NS & 0.02 \\
\hline DM $(\%)$ & 14.6 & 15.4 & 15.9 & 14.9 & 15.7 & 14.3 & 0.6 & NS & 0.18 & NS & NS & 0.04 \\
\hline $\mathrm{DM}(\mathrm{kg})$ & 10.6 & 10.1 & 11.0 & 10.2 & 9.1 & 9.6 & 0.4 & $<0.01$ & 0.16 & 0.06 & 0.19 & NS \\
\hline Liquid passage rate (\%/h) & 10.8 & 11.3 & 9.4 & 10.3 & 10.6 & 9.7 & 0.7 & NS & NS & 0.05 & NS & NS \\
\hline Particle passage rate $(\% / \mathrm{h})$ & 4.94 & 5.19 & 3.33 & 5.12 & 4.91 & 4.26 & 0.44 & NS & 0.13 & 0.01 & NS & 0.20 \\
\hline
\end{tabular}

${ }^{1}$ Rumensin supplementation (12 g/909 kg of DM); AV fat: $5.0 \%$ added AV blend; CNO: $5.0 \%$ added CNO.

${ }^{2}$ Standard error of the mean for $\mathrm{n}=6$.

${ }^{3}$ Probability of a treatment response; NS: $P>0.20$. Contrasts compared the main effect of $\mathrm{R}$ (diets without vs. with $\mathrm{R}$ averaged over fat treatments), the main effect of fat (Fat $=$ control vs. the average of the 2 fat diets averaged over $\mathrm{R}$ ), the main effect of source of fat (source $=$ AV fat vs. CNO averaged over $\mathrm{R}$ ), the interaction between $\mathrm{R}$ and fat $(\mathrm{R} \times$ fat), and the interaction between $\mathrm{R}$ and source of fat $(\mathrm{R} \times$ source). See Materials and Methods section for contrasts.

${ }^{4}$ Total pool sizes of wet digesta were determined by the average of $2 \mathrm{~d}$ of rumen evacuations.

${ }^{5}$ Liquid separated from rumen contents using a wine press.

Table 6. Least squares means for OM and NDF digestibility for cows fed diets without or with Rumensin (R) and without or with $5 \%$ fat from animal-vegetable (AV) fat or coconut oil $(\mathrm{CNO})$

$\operatorname{Diet}^{1}$

\begin{tabular}{|c|c|c|c|c|c|c|c|c|c|c|c|c|}
\hline \multirow[b]{3}{*}{ Item } & \multicolumn{6}{|c|}{ Diet $^{1}$} & \multirow[b]{3}{*}{$\mathrm{SEM}^{2}$} & \multirow{2}{*}{\multicolumn{5}{|c|}{$P$-value ${ }^{3}$}} \\
\hline & \multicolumn{3}{|c|}{$-\mathrm{R}$} & \multicolumn{3}{|c|}{$+\mathrm{R}$} & & & & & & \\
\hline & Control & AV fat & $\mathrm{CNO}$ & Control & $\mathrm{AV}$ fat & $\mathrm{CNO}$ & & $\mathrm{R}$ & Fat & Source & $\mathrm{R} \times$ fat & $\mathrm{R} \times$ source \\
\hline $\begin{array}{l}\text { OM intake }(\mathrm{kg} / \mathrm{d}) \\
\text { OM digestibility }(\%)\end{array}$ & 18.9 & 18.8 & 14.9 & 18.4 & 18.2 & 14.0 & 0.6 & 0.08 & $<0.01$ & $<0.01$ & NS & NS \\
\hline Apparent ruminal & 42.9 & 38.8 & 42.6 & 38.3 & 43.2 & 43.6 & 2.5 & NS & NS & NS & 0.13 & NS \\
\hline Apparent total tract & 70.0 & 69.7 & 69.8 & 67.9 & 72.7 & 69.0 & 1.2 & NS & NS & 0.17 & 0.16 & 0.14 \\
\hline NDF intake $(\mathrm{kg} / \mathrm{d})$ & 6.8 & 5.9 & 4.5 & 6.8 & 5.7 & 4.3 & 0.2 & NS & $<0.01$ & $<0.01$ & NS & NS \\
\hline NDF digestibility (\%) & & & & & & & & & & & & \\
\hline Ruminal & 33.8 & 32.1 & 31.6 & 28.3 & 28.8 & 16.0 & 4.2 & 0.04 & NS & 0.17 & NS & 0.19 \\
\hline Total tract & 58.8 & 51.8 & 44.1 & 55.1 & 57.3 & 47.4 & 2.6 & NS & $<0.01$ & $<0.01$ & 0.09 & NS \\
\hline Ruminal digestibility ( $\%$ total tract) & 58.7 & 63.0 & 75.4 & 55.2 & 50.4 & 33.6 & 9.0 & 0.03 & NS & NS & 0.17 & 0.15 \\
\hline
\end{tabular}

$\leqslant \quad{ }^{1}$ Rumensin supplementation (12 g/909 kg of DM); AV fat: $5.0 \%$ added AV blend; CNO: $5.0 \%$ added CNO.

${ }^{2}$ Standard error of the mean for $\mathrm{n}=6$.

$\mathbf{Z} \quad{ }^{3}$ Probability of a treatment response; NS: $P>0.20$. Contrasts compared the main effect of $\mathrm{R}$ (diets without vs. with $\mathrm{R}$ averaged over fat treatments), the main effect of fat (Fat . = control vs. the average of the 2 fat diets averaged over $\mathrm{R}$ ), the main effect of source of fat (source $=\mathrm{AV}$ fat vs. CNO averaged over $\mathrm{R}$ ), the interaction between $\mathrm{R}$ and fat $(\mathrm{R} \times$

fat), and the interaction between $\mathrm{R}$ and source of fat $(\mathrm{R} \times$ source $)$. See Materials and Methods section for contrasts. 
creased with fat addition (fat effect). The molar percentage of acetate decreased by 5.7 percentage units by fat and was 4.3 percentage units lower with $\mathrm{CNO}$ than with AV fat (fat source effect). Molar percentages of butyrate and isovalerate generally followed similar patterns as did acetate, but propionate and valerate tended to be increased by CNO (fat source effect). The combined responses of acetate and propionate decreased acetate-to-propionate ratio with fat addition and particularly for CNO (fat source effect; 2.58 for $\mathrm{AV}$ fat vs. 1.85 for $\mathrm{CNO}$ ). The main effects of $\mathrm{R}$ and fat source were significant for isobutyrate molar percentage; however, the $\mathrm{R} \times$ fat source interaction was a result of $\mathrm{R}$ increasing isobutyrate with $\mathrm{AV}$ fat but not with $\mathrm{CNO}$. Ruminal $\mathrm{NH}_{3}-\mathrm{N}$ concentration was not affected by treatment.

\section{Pool Size and Passage Kinetics}

Averaged over control or fat treatments, ruminal mass (total of liquid + DM) decreased by $4.9 \mathrm{~kg}$ with $\mathrm{R}$ supplementation (Table 5). Averaged over R effects, adding fat (fat main effect) decreased ruminal mass, with AV fat having a larger decrease than CNO (fat source main effect). When assessed as the fluid removed by squeezing through a wine press, which closely approximates the volume of fluid around particles (Karnati et al., 2007), the ruminal liquid decreased with fat supplementation. The $\mathrm{R} \times$ fat source interaction was detected when both AV fat and CNO decreased ruminal liquid without $\mathrm{R}$, but with $\mathrm{R}$, the ruminal liquid pool decreased for AV fat but increased for CNO. The same interaction in reverse is shown for DM percentage. The mass of DM in the rumen decreased by $0.9 \mathrm{~kg}$ with the main effect of R supplementation. Supplementing CNO decreased both fluid and particulate passage rates from the rumen compared with $\mathrm{AV}$ fat.

\section{Ruminal and Total-Tract Digestibility}

The intake of OM tended $(P<0.08)$ to be depressed by the addition of $\mathrm{R}$ and was decreased when fat was added and especially $(4.0 \mathrm{~kg} / \mathrm{d})$ when cows were fed CNO versus AV fat (Table 6). No difference was detected in apparent ruminal or total-tract digestibilities of OM. The NDF intake responses were similar to OM intake. The ruminal NDF digestibility was decreased by the main effect of R. The NDF digestibility in the total tract was decreased by fat, but especially for $\mathrm{CNO}$ (main effect of fat source). The $\mathrm{R} \times$ fat interaction $(P$ $=0.09$ ) for total-tract NDF digestibility was detected when fat sources without $\mathrm{R}$ had lower digestibilities than with R. The ruminal NDF digestibility as a percentage of total-tract digestibility was lower with $\mathrm{R}$ supplementation, documenting a shift in the site of digestion to the lower tract.

Averaged over fat treatments, cows fed diets without $\mathrm{R}$ tended $(P<0.06)$ to have greater $\mathrm{N}$ intakes than those fed R (Table 7). When fed fat, cows decreased $\mathrm{N}$ intake, with most of the depression a result of $\mathrm{CNO}$ (main effect of fat source). Correspondingly, main effects for fat and fat source were detected for the flows of total $\mathrm{N}$ and microbial $\mathrm{N}$ to the omasum, which were 103 and $78 \mathrm{~g} / \mathrm{d}$ lower for CNO than for AV fat, respectively. No differences in non-ammonia non-microbial $\mathrm{N}$ or EMPS were detected. Apparent total-tract $\mathrm{N}$ digestibility was about 4.8 percentage units higher $(P<0.01)$ for the average of fat treatments compared with the control.

\section{Lactation Performance}

The trend $(P<0.08)$ for the main effect of $\mathrm{R}$ and lack of interactions for $\mathrm{R} \times$ fat or $\mathrm{R} \times$ fat source document a small but consistent decrease in DMI of about $0.7 \mathrm{~kg} / \mathrm{d}$ resulting from feeding $\mathrm{R}$ (Table 8 ). The DMI decreased for fat compared with control, but this response was primarily driven by the main effect means for CNO being $4.2 \mathrm{~kg} / \mathrm{d}$ lower than AV fat (fat source main effect). Correspondingly, milk production was decreased by $2.6 \mathrm{~kg} / \mathrm{d}$ with $\mathrm{CNO}$ compared with AV fat. Lactose concentration and production tended $(P$ $<0.09$ ) to be decreased by $\mathrm{R}$ and were decreased by fat and source of fat, closely following trends for milk production. Milk protein percentage tended $(P<0.08)$ to be lower when cows were fed fat (fat main effect), but milk protein production was lower $(P<0.01)$ for the average of fat treatments compared with control and for CNO compared with AV fat (fat source effect). For MUN, the main effect of fat was from AV fat being lower than CNO.

Supplementing dietary fat sources decreased milk fat percentage, and CNO depressed fat by a further $0.47 \%$ units compared with AV fat (fat source effect). Milk fat production was decreased by feeding both fats. Although the main effect of fat source resulted from a further decrease in milk fat production from CNO than AV fat, the trend $(P<0.10)$ for an $\mathrm{R} \times$ fat source interaction indicated that AV fat depressed milk fat production, especially when $\mathrm{R}$ was added; the depressed fat production for $\mathrm{AV}$ fat with $\mathrm{R}$ more closely approximated the low fat production when cows were fed CNO (i.e., when milk fat:protein inversion occurred). The $\mathrm{R}$ $\times$ fat source interaction was similar for $3.5 \%$ FCM and ECM as described for milk fat production. No treatment effects on BW were observed. 
Table 7. Least squares means for N digestibility for cows fed diets without or with Rumensin (R) and without or with $5 \%$ fat from animal-vegetable (AV) fat or coconut oil (CNO)

\begin{tabular}{|c|c|c|c|c|c|c|c|c|c|c|c|c|}
\hline \multirow[b]{3}{*}{ Item } & \multicolumn{6}{|c|}{$\operatorname{Diet}^{1}$} & \multirow[b]{3}{*}{$\mathrm{SEM}^{2}$} & \multirow{2}{*}{\multicolumn{5}{|c|}{$P$-value ${ }^{3}$}} \\
\hline & \multicolumn{3}{|c|}{$-\mathrm{R}$} & \multicolumn{3}{|c|}{$+\mathrm{R}$} & & & & & & \\
\hline & Control & AV fat & $\mathrm{CNO}$ & Control & AV fat & $\mathrm{CNO}$ & & $\mathrm{R}$ & Fat & Source & $\mathrm{R} \times$ fat & $\mathrm{R} \times$ source \\
\hline $\mathrm{N}$ intake $(\mathrm{g} / \mathrm{d})$ & 539 & 528 & 432 & 519 & 527 & 393 & 18 & 0.06 & $<0.01$ & $<0.01$ & NS & 0.15 \\
\hline Omasal flow (g/d) & 482 & 514 & 384 & 512 & 445 & 369 & 25 & NS & $<0.01$ & $<0.01$ & 0.13 & NS \\
\hline Microbial N (g/d) & 335 & 347 & 253 & 346 & 309 & 248 & 19 & NS & 0.01 & $<0.01$ & NS & NS \\
\hline $\mathrm{NANMN}^{4}(\mathrm{~g} / \mathrm{d})$ & 148 & 167 & 131 & 166 & 135 & 124 & 14 & NS & 0.20 & 0.16 & 0.15 & NS \\
\hline NANMN (\% of N intake) & 27.2 & 31.7 & 29.3 & 31.8 & 25.7 & 30.4 & 2.7 & NS & NS & NS & 0.17 & NS \\
\hline EMPS $^{5}$ (g of N/kg of OM apparently digested) & 42.3 & 48.7 & 39.4 & 55.7 & 40.2 & 45.3 & 5.1 & NS & NS & NS & 0.14 & NS \\
\hline Apparent total-tract $\mathrm{N}$ digestibility (\%) & 73.0 & 74.5 & 77.7 & 71.8 & 78.2 & 78.5 & 1.3 & NS & $<0.01$ & 0.20 & 0.14 & NS \\
\hline
\end{tabular}

${ }^{1}$ Rumensin supplementation (12 g/909 kg of DM); AV fat: $5.0 \%$ added AV blend; CNO: $5.0 \%$ added CNO.

${ }^{2}$ Standard error of the mean for $\mathrm{n}=6$.

${ }^{3}$ Probability of a treatment response; NS: $P>0.20$. Contrasts compared the main effect of $\mathrm{R}$ (diets without vs. with $\mathrm{R}$ averaged over fat treatments), the main effect of fat (Fat $=$ control vs. the average of the 2 fat diets averaged over $R$ ), the main effect of source of fat (source $=A V$ fat vs. $C N O$ averaged over $R$ ), the interaction between $R$ and fat ( $\mathrm{R} \times$ fat), and the interaction between $\mathrm{R}$ and source of fat $(\mathrm{R} \times$ source). See Materials and Methods section for contrasts.

${ }^{4}$ Non-ammonia non-microbial nitrogen.

${ }^{5}$ Efficiency of microbial protein synthesis.

Table 8. Least squares means for lactation performance for cows fed diets without or with Rumensin (R) and without or with $5 \%$ fat from animal-vegetable (AV) fat or coconut oil $(\mathrm{CNO})$

\begin{tabular}{|c|c|c|c|c|c|c|c|c|c|c|c|c|}
\hline \multirow[b]{3}{*}{ Item } & \multicolumn{6}{|c|}{ Diet $^{1}$} & \multirow[b]{3}{*}{$\mathrm{SEM}^{2}$} & \multirow{2}{*}{\multicolumn{5}{|c|}{$P$-value ${ }^{3}$}} \\
\hline & \multicolumn{3}{|c|}{$-\mathrm{R}$} & \multicolumn{3}{|c|}{$+\mathrm{R}$} & & & & & & \\
\hline & Control & $\mathrm{AV}$ fat & $\mathrm{CNO}$ & Control & $\mathrm{AV}$ fat & $\mathrm{CNO}$ & & $\mathrm{R}$ & Fat & Source & $\mathrm{R} \times$ fat & $\mathrm{R} \times$ source \\
\hline DMI (kg/d) & 20.0 & 19.8 & 15.5 & 19.3 & 19.0 & 14.8 & 0.7 & 0.08 & $<0.01$ & $<0.01$ & NS & NS \\
\hline Milk (kg/d) & 33.9 & 34.3 & 30.5 & 33.1 & 31.7 & 30.3 & 2.0 & 0.07 & 0.01 & $<0.01$ & NS & 0.13 \\
\hline Lactose (\%) & 4.82 & 4.72 & 4.48 & 4.81 & 4.68 & 4.50 & 0.07 & NS & $<0.01$ & $<0.01$ & NS & NS \\
\hline Lactose (kg/d) & 1.63 & 1.62 & 1.36 & 1.59 & 1.48 & 1.36 & 0.08 & 0.09 & $<0.01$ & $<0.01$ & NS & 0.12 \\
\hline Milk protein (\%) & 2.92 & 2.80 & 2.74 & 2.87 & 2.89 & 2.72 & 0.08 & NS & 0.08 & 0.11 & NS & NS \\
\hline Milk protein $(\mathrm{kg} / \mathrm{d})$ & 0.99 & 0.96 & 0.83 & 0.94 & 0.91 & 0.83 & 0.05 & 0.13 & $<0.01$ & $<0.01$ & NS & NS \\
\hline $\operatorname{MUN}(\mathrm{mg} / \mathrm{dL})$ & 14.1 & 12.6 & 15.5 & 15.3 & 14.0 & 14.8 & 0.8 & NS & NS & 0.02 & NS & 0.18 \\
\hline Milk fat $(\%)$ & 3.23 & 2.96 & 2.37 & 3.18 & 2.79 & 2.45 & 0.19 & NS & $<0.01$ & $<0.01$ & NS & NS \\
\hline Milk fat $(\mathrm{kg} / \mathrm{d})$ & 1.08 & 1.01 & 0.71 & 1.05 & 0.87 & 0.73 & 0.05 & 0.14 & $<0.01$ & $<0.01$ & NS & 0.10 \\
\hline $\mathrm{FCM}^{4}(\mathrm{~kg})$ & 32.2 & 31.1 & 24.7 & 31.2 & 27.7 & 24.8 & 1.4 & 0.06 & $<0.01$ & $<0.01$ & NS & 0.07 \\
\hline ECM (kg) & 32.2 & 31.2 & 25.2 & 31.1 & 28.1 & 25.2 & 1.3 & 0.05 & $<0.01$ & $<0.01$ & NS & 0.08 \\
\hline $\mathrm{BW}(\mathrm{kg})$ & 577 & 573 & 578 & 568 & 560 & 578 & 19 & NS & NS & 0.11 & NS & NS \\
\hline
\end{tabular}




\section{DISCUSSION}

\section{Protozoal Abundance}

Rumensin had minor effects on protozoa, probably because of our transfaunation between periods (Table 3). Although protozoa show sensitivity to R, they adapt quickly in vitro (Sylvester et al., 2009) and in vivo (Towne et al., 1990). For lactating cattle in a Latin square, $\mathrm{R}$ had minor effects on protozoal counts (Oelker et al., 2009; Mathew et al., 2011). However, in a 16-wk feedlot study, protozoal numbers were not restored until 3 to 6 wk of feeding $\mathrm{R}$ (Guan et al., 2006). Thus, because we noted dose responsiveness for protozoal cultures (Sylvester et al., 2009), differences might exist among beef versus dairy because of different effective dosage rates of $\mathrm{R}$ when scaled to DMI or other responses related to forage:concentrate ratio.

The main effect of fat addition was mainly due to a result of the effect of $\mathrm{CNO}$ versus $\mathrm{AV}$ fat. When individual MCFA were evaluated to control protozoal abundance, lauric acid was confirmed as the causative agent in CNO (Hristov et al., 2009). Even though PUFA can decrease protozoal numbers, the effect of supplemental fats high in PUFA is inconsistent (Doreau and Ferlay, 1995). Increasing the inclusion amount of fat (Onetti et al., 2001) or degree of FA unsaturation can decrease protozoal counts (Oldick and Firkins, 2000). However, reaching a threshold of concentration of bioactive FA concentration to influence $\mathrm{BH}$ flux or pathway probably interacts with the type and availability of FA and other dietary characteristics such as forage NDF concentration and feeding frequency. In addition, protozoal abundance was significantly decreased when $3 \%$ linseed oil addition was combined with a high-concentrate diet (Ueda et al., 2003). A generally greater inhibition by fat with increasing carbohydrate availability has been recognized (Firkins, 1996). Higher concentrate decreases the rate of $\mathrm{BH}$ (Jenkins et al., 2008) and could lead to a more prolonged inhibition.

To our knowledge, a mechanism of inhibition by FA has not been established for protozoa. Apparently, the FA need to have a free carboxyl group before being toxic (Sutton et al., 1983; Yabuuchi et al., 2006). Protozoa consume feed particles (to which FA can adsorb) and bacteria and preferentially incorporate unsaturated and partially biohydrogenated FA into their lipids (Devillard et al., 2006), presumably membranes (Or-Rashid et al., 2007). Monensin was postulated to interfere with organelle membrane function until the cells adapt (Sylvester et al., 2009). Similar to our current results, Epidinium was the only genus counted that did not greatly decrease when CNO was fed to goats (Matsumoto et al., 1991). Epidinium is unique because it momentarily attaches to physically tear off pieces of the plant cell walls (Dehority, 2010), but it is not known why it has lower sensitivity to MCFA. Although Epidinium was not detected for $\mathrm{CNO}$ or lauric acid treatments (Hristov et al., 2009; Hristov et al., 2011), low Epidinium counts in general (i.e., in the control) might have caused them to drop below the detection limit of their counting methods.

\section{Ruminal Fermentation}

The major benefit of feeding $\mathrm{R}$ is usually attributed to inhibition of gram-positive bacteria and a shift of fermentation from acetate to propionate production (Ipharraguerre and Clark, 2003) along with a transient decrease in methane production up to 4 wk after introduction in the diet (Guan et al., 2006). As with our previous studies (Oelker et al., 2009; Mathew et al., 2011), we did not observe a decreased acetate:propionate ratio with R (Table 4), but isobutyrate molar percentage increased in the current study and in that of Mathew et al. (2011). Strain differences in extracellular architecture help gram-positive bacteria adapt to monensin in vitro (Russell and Houlihan, 2003) and probably in vivo (Weimer et al., 2008).

We report here a significant shift of fermentation from acetate, butyrate, and isovalerate toward propionate and valerate with the addition of fat, especially with CNO compared with AV fat. Because propionate and valerate are important hydrogen sinks, we would expect a resultant decrease in methane production per unit of DMI. Ferlay and Doreau (1992) described a shift from acetate to propionate with increasing supplementation of rapeseed oil. The acetate:propionate ratio was decreased by lauric acid (Hristov et al., 2011) and by CNO in one study (Sutton et al., 1983) but not another (Hristov et al., 2009). Defaunation often decreases butyrate (Eugène et al., 2004), and protozoa decreased concomitantly with the butyrate in cattle fed CNO. However, further clarification is needed to differentiate the relative responses of $\mathrm{CNO}$ to protozoa versus other microbial populations involved in interspecies hydrogen transfer, thus explaining variable responses in VFA profiles (Hristov et al., 2009).

\section{Pool Size and Passage Kinetics}

We measured a decrease in ruminal mass of total contents and DM when $\mathrm{R}$ was fed, but no changes in passage rates occurred (Table 5). The supplementation of $\mathrm{R}$ decreased ruminal turnover rate and increased $\mathrm{ru}-$ minal fill in beef cattle (Schelling, 1984), but we are not aware of a similar reported response with dairy cattle. 
Our results are consistent with a small but consistent decrease $(P<0.08)$ in DMI (Table 8$)$.

The ruminal mass and ruminal liquid pool sizes were lower for supplementation of AV fat compared with CNO, even though DMI was depressed much more for CNO. According to Doreau and Ferlay (1995), the supplementation of fat should not modify liquid volume or liquid turnover rate. Both liquid and solid passages rates were decreased with $\mathrm{CNO}$ compared with $\mathrm{AV}$ fat, but these results are likely a result of depressed DMI.

\section{Rationale for Flow Marker Choice}

We recognize the likelihood that omasal sampling can bias for fluid and against large particles, as documented by previous authors (Ahvenjärvi et al., 2001). The mathematical correction of the double- or triple-marker methods reconstitutes actual digesta by adding or subtracting the amount of particulates needed to mathematically predict a sample representing true digesta. Although the mathematical assumptions have not been challenged, researchers are not determining true digesta flow but, rather, an estimate of true digesta flow. Therefore, as marker ratios approach their limits (i.e., when 2 markers converge toward distributing similarly among phases), we reasoned that relatively small errors in quantification of markers from their true concentrations could have increasing sensitivity to increase the deviation in estimated versus actual true digesta flow.

We were concerned that the typical 3-marker approach (Ahvenjärvi et al., 2000) might be positively biased by the direct infusion of $\mathrm{Yb}$, which has largely been rejected as a single marker. In addition to extensive migration to small particles and bacteria, which helps justify its use to mark small particles, a significant but unknown proportion of $\mathrm{Yb}$ precipitates as Yb salts (Bernard and Doreau, 2000). Huhtanen et al. (1997) noted that $\mathrm{Yb}$ had a higher concentration in liquid than particulate matter (50.4 vs. $38.4 \mathrm{mg} /$ $\mathrm{kg}$ ). Small particles have long been held to pass with the fluid more than with the particulate phase $(\mathrm{Ow}-$ ens and Goetsch, 1986). A correlation of 0.99 between flows derived from using only Co-EDTA or infused $\mathrm{Yb}$ as single markers (Ipharraguerre et al., 2007) suggests that Co-EDTA and infused $\mathrm{Yb}$ can approach limits of marking the same phase.

Our intention was to mark corn silage (the predominant forage) particles that were retained on a $1.18-\mathrm{mm}$ screen using a $\mathrm{Yb}$ application, soaking, and rinsing to remove most of the $\mathrm{Yb}$ bound to low-affinity sites (Ellis et al., 2002) in a double-marker system (Siddons et al., 1985). Huhtanen et al. (2010) have used statistical analyses to argue for a 3-marker approach over a 2-marker approach. However, this post hoc analysis never compared 3-marker approaches using infused $\mathrm{Yb}$ versus 2-marker approaches using Yb-marked feed. The 1.18-mm screen has been justified for particles stimulating rumination (Mertens, 1997), allowing representation of small particles from rumination and resulting comminution. The average rate of migration of $\mathrm{Yb}$ was about $0.005 / \mathrm{h}$ (Bernard and Doreau, 2000), which is about one-tenth of our $\mathrm{Yb}$ turnover rates. Thus, we assumed that our marking of larger particles would distribute $\mathrm{Yb}$ not just to those particles, but also to smaller particles through comminution and migration.

Although we planned to use a double-marker approach and do not advocate the use of a single marker for omasal flow studies, the flow values and digestibilities were highly variable in the current study; NDF digestibilities occasionally were either negative or exceeded $100 \%$. In contrast with our previous experience (Noftsger et al., 2005), further subdivision of aliquots from the individual omasal samples (for measurements not reported herein) apparently biased these subsamples using the reconstitution protocol and amplified errors in our predicted nutrient flows. Instead of subsampling whole omasal contents, we probably should have separated into phases first and then subsampled from the phases (Huhtanen et al., 1997).

Relatively little direct evidence supports or refutes the necessary assumption that omasal sampling with our $\mathrm{Yb}$ marking approach does or does not bias amongtreatment comparisons. Most forage particles undergo comminution to a size (Mertens, 1997) small enough to pass through the opening of the modified omasal sampling tube we used (Ahvenjärvi et al., 2001), and we were very careful to retain omasal samples only when no occlusion of the sampling tube existed to prevent the possible under-representation of large particles (Ipharraguerre et al., 2007; Broderick et al., 2010). Moreover, our prior experience (Noftsger et al., 2005 ) with a 2-marker approach documented only approximately $10 \%$ average mathematical reconstitution of particles was needed (data not shown). In contrast, Huhtanen et al. (2010) have argued that a single $\mathrm{Cr}_{2} \mathrm{O}_{3}$ marker underestimated ruminal NDF digestibility in the meta-analysis by Firkins (1997) compared with expectations for data using a 3-marker system. However, one data set in the latter used only total diversion duodenal cannulas (theoretically not allowing under- or over-representation of particles) and had ruminal NDF digestibilities for dairy cows that averaged near the value of our control treatment. Huhtanen et al. (2010) have argued for NDF digestibility in the omasum to explain the difference, but this explanation is not supported by reticular sampling (Krizsan et al., 2010) or the 10-h residence time in the intestines (Wylie et al., 2000). We acknowledge that ruminal NDF digest- 
ibilities might be less accurate or more variable in the current study using $\mathrm{Yb}$ as a single marker, but the errors should be equally and randomly distributed across treatments.

\section{Omasal Flow and Site of Digestion}

Ruminal and total-tract apparent digestibilities of OM were not different with diet (Table 6). However, supplementation of $\mathrm{R}$ decreased ruminal NDF digestibility without decreasing total-tract digestibility and potentially even improving NDF digestibility when fat was fed $(\mathrm{R} \times$ fat, $P<0.09)$. Although apparently not well studied, such a shift to the lower tract was noted previously (McGuffey et al., 2001). Feeding CNO numerically decreased NDF digestibility in the rumen and significantly depressed total-tract NDF digestibility. Previously, Oldick and Firkins (2000) found a decrease in ruminal and total-tract NDF digestibilities when fat was fed but no effect of fat saturation. However, Pantoja et al. (1994) reported that ruminal NDF digestibility decreased with increasing fat unsaturation, and site of digestion was shifted more to the hindgut. With feeding 7\% CNO of DM to sheep, no differences occurred in total-tract OM digestibility, but Machmüller and Kreuzer (1999) also reported a nonsignificant 9 -percentage unit decrease in NDF digestibility in the total tract. Lauric acid or CNO can decrease the activity of fibrolytic enzymes (Hristov et al., 2004b; Hristov et al., 2009), but NDF digestibility was not depressed (Hristov et al., 2004b; Hristov et al., 2011) or only numerically $(P=0.13)$ decreased (Hristov et al., 2009).

The omasal flow of $\mathrm{N}$ components was decreased by CNO supplementation, mostly because of the decreased $\mathrm{N}$ intake (Table 7), which was associated with a decreased DMI (Table 8). When corrected for differences in $\mathrm{N}$ intake, non-ammonia non-microbial $\mathrm{N}$ was not different (Table 7). As demonstrated using a metaanalysis, the major factor affecting microbial $\mathrm{N}$ flow from the rumen is DMI (Oldick et al., 1999), and when lauric acid decreased DMI, it also decreased urinary excretion of purine derivatives (Hristov et al., 2011). We did not observe a change in EMPS with $\mathrm{R}$ or even for fat, as expected (Oldick and Firkins, 2000). Sutton et al. (1983) observed a significant increase of EMPS with supplementation of linseed oil or CNO, although the calculation was largely a result of decreased OM digestibility in the rumen. In fact, defaunation typically increases EMPS, but the more modest increase of microbial $\mathrm{N}$ supply to the cow might be offset by the decrease in $\mathrm{OM}$ or NDF digestibility, reducing $\mathrm{NE}_{\mathrm{L}}$ supply (Firkins et al., 2007). If bacterial recycling was reduced by $\mathrm{CNO}$ as a result of the profound inhibition of ruminal protozoa (Table 3 ), the slower passage rates
(Table 5) might have negated the benefit by decreasing EMPS (Firkins et al., 1992).

\section{Intake and Milk Production}

We noted a drastic decrease in DMI when CNO was supplemented (Table 8). Hristov et al. (2004a) also dosed $480 \mathrm{~g} / \mathrm{d}$ of lauric acid directly into the rumen and observed an inhibition of feed intake, whereas DMI was restored at $240 \mathrm{~g} / \mathrm{d}$ of lauric acid. In subsequent studies, DMI was maintained (Hristov et al., 2009) or depressed by over $5 \mathrm{~kg} / \mathrm{d}$ (Hristov et al., 2011), but mixed results cannot be attributed to palatability because lauric acid was dosed intraruminally. Although CNO numerically decreased ruminal NDF digestibility and decreased particulate passage rate from the rumen, metabolic appetite control from MCFA (Allen et al., 2009), as discussed further in our companion paper (Reveneau et al., 2012) probably explains most of the dramatic decrease in DMI from CNO in our study. The tendency for R to decrease DMI (often increasing feed efficiency) has been noted (Ipharraguerre and Clark, 2003).

We observed a severe decrease in milk production, milk fat percentage, and milk fat yield with CNO added to the diet. Hristov et al. (2009) did not detect any depression in milk fat production by lauric acid or CNO, but lauric acid depressed milk fat production extensively in a subsequent study (Hristov et al., 2011). The results appear to be related to varying 18:1 trans-10 isomers and altered $\mathrm{BH}$. In our experiment, DMI must have limited the energy available for lactation for the CNO diets, as indicated by lower production of lactose and protein.

The interactions $(P<0.08)$ for $\mathrm{R} \times$ fat source for FCM and ECM production demonstrate the effect of R combined with $\mathrm{AV}$ fat at decreasing milk fat production $(P<0.10)$. This combination also had milk fat:protein inversion, as did both $\mathrm{CNO}$ diets. The changes in FA ruminal metabolism and subsequent changes in milk FA secretion are described in the companion paper (Reveneau et al., 2012).

\section{CONCLUSIONS}

The addition of CNO in the diet greatly suppressed protozoal abundance. The fermentation shifted toward the hydrogen sinks, propionate and valerate. The changes in VFA were associated with a trend for decreased ruminal digestibility. Significantly decreased total-tract digestibility of NDF and DMI for CNO suppressed milk production. Although consistent with expectations for decreased protozoal abundance, CNO did not improve EMPS. Dry matter intake and milk production was 
also decreased with $\mathrm{R}$. With our high inclusion rates of supplemental fat, milk fat depression was prevalent with $\mathrm{CNO}$ and also with AV fat more when supplemented with $\mathrm{R}$ than without $\mathrm{R}$, even though diets were fed every $2 \mathrm{~h}$ to reduce accumulation of bioactive $\mathrm{BH}$ intermediates.

\section{REFERENCES}

Ahvenjärvi, S., B. Skiba, and P. Huhtanen. 2001. Effect of heterogeneous digesta chemical composition on the accuracy of measurements of fiber flow in dairy cows. J. Anim. Sci. 79:1611-1620.

Ahvenjärvi, S., A. Vanhatalo, P. Huhtanen, and T. Varvikko. 2000. Determination of reticulo-rumen and whole-stomach digestion in lactating cows by omasal canal or duodenal sampling. Br. J. Nutr. $83: 67-77$

Allen, M. S., B. J. Bradford, and M. Oba. 2009. Board-invited review: The hepatic oxidation theory of the control of feed intake and its application to ruminants. J. Anim. Sci. 87:3317-3334.

AOAC. 1990. Official Methods of Analysis. 15th ed. Association of Official Analytical Chemists, Arlington, VA.

Bernard, L., and M. Doreau. 2000. Use of rare earth elements as external markers for mean retention time measurements in ruminants. Reprod. Nutr. Dev. 40:89-101.

Broderick, G. A., P. Huhtanen, S. Ahvenjärvi, S. M. Reynal, and K. J. Shingfield. 2010. Quantifying ruminal nitrogen metabolism using the omasal sampling technique in cattle - A meta-analysis. J. Dairy Sci. 93:3216-3230.

Dehority, B. A. 1993. Laboratory Manual for Classification and Morphology of Rumen Ciliate Protozoa. CRC Press Inc., Boca Raton, FL.

Dehority, B. A. 2010. Physiological characteristics of several rumen protozoa grown in vitro with observations on within and among species variation. Eur. J. Protistol. 46:271-279.

Devillard, E., F. M. McIntosh, C. J. Newbold, and R. J. Wallace. 2006. Rumen ciliate protozoa contain high concentrations of conjugated linoleic acids and vaccenic acid, yet do not hydrogenate linoleic acid or desaturate stearic acid. Br. J. Nutr. 96:697-704.

Doreau, M., and A. Ferlay. 1995. Effect of dietary lipids on nitrogen metabolism in the rumen: A review. Livest. Prod. Sci. 43:97-110.

Ellis, W. C., M. J. Wylie, and J. H. Matis. 2002. Validity of specifically applied rare earth elements and compartmental models for estimating flux of undigested plant tissue residues through the gastrointestinal tract of ruminants. J. Anim. Sci. 80:2753-2758.

Eugène, M., H. Archimède, and D. Sauvant. 2004. Quantitative metaanalysis on the effects of defaunation of the rumen on growth, intake and digestion in ruminants. Livest. Prod. Sci. 85:81-97.

Ferlay, A., and M. Doreau. 1992. Influence of method of administration of rapeseed oil in dairy cows. 1. Digestion of nonlipid components. J. Dairy Sci. 75:3020-3027.

Firkins, J. L. 1996. Maximizing microbial protein synthesis in the rumen. J. Nutr. 126:1347S-1354S.

Firkins, J. L. 1997. Effects of feeding nonforage fiber sources on site of fiber digestion. J. Dairy Sci. 80:1426-1437.

Firkins, J. L., S. K. R. Karnati, and Z. Yu. 2008. Linking rumen function to animal response by application of metagenomics techniques. Aust. J. Exp. Agric. 48:711-721.

Firkins, J. L., W. P. Weiss, and E. J. Piwonka. 1992. Quantification of intraruminal recycling of microbial nitrogen using nitrogen-15. J. Anim. Sci. 70:3223-3233.

Firkins, J. L., Z. Yu, and M. Morrison. 2007. Ruminal nitrogen metabolism: Perspectives for integration of microbiology and nutrition for dairy. J. Dairy Sci. 90(E. Suppl.):E1-E16.

Guan, H., K. M. Wittenberg, K. H. Ominski, and D. O. Krause. 2006. Efficacy of ionophores in cattle diets for mitigation of enteric methane. J. Anim. Sci. 84:1896-1906.

Harvatine, D. I., J. L. Firkins, and M. L. Eastridge. 2002. Whole linted cottonseed as a forage substitute fed with ground or steam-flaked corn: Digestibility and performance. J. Dairy Sci. 85:1976-1987.
Hristov, A. N., and G. A. Broderick. 1996. Synthesis of microbial protein in ruminally cannulated cows fed alfalfa silage, alfalfa hay, or corn silage. J. Dairy Sci. 79:1627-1637.

Hristov, A. N., R. P. Etter, J. K. Ropp, and K. L. Grandeen. 2004a. Effect of dietary crude protein level and degradability on ruminal fermentation and nitrogen utilization in lactating dairy cows. J. Anim. Sci. 82:3219-3229.

Hristov, A. N., K. L. Grandeen, J. K. Ropp, and M. A. McGuire. 2004b. Effect of sodium laurate on ruminal fermentation and utilization of ruminal ammonia nitrogen for milk protein synthesis in dairy cows. J. Dairy Sci. 87:1820-1831.

Hristov, A. N., M. Ivan, and T. A. McAllister. 2004c. In vitro effects of individual fatty acids on protozoal numbers and on fermentation products in ruminal fluid from cattle fed a high-concentrate, barley-based diet. J. Anim. Sci. 82:2693-2704.

Hristov, A. N., and J.-P. Jouany. 2005. Factors affecting the efficiency of nitrogen utilization in the rumen. Pages 117-166 in Nitrogen and Phosphorus Nutrition of Cattle and Environment. A. N. Hristov and E. Pfeffer, ed. CAB International, Wallingford, UK.

Hristov, A. N., C. Lee, T. Cassidy, M. Long, K. Heyler, B. Corl, and R. Forster. 2011. Effects of lauric and myristic acids on ruminal fermentation, production, and milk fatty acid composition in lactating dairy cows. J. Dairy Sci. 94:382-395.

Hristov, A. N., M. Vander Pol, M. Agle, S. Zaman, C. Schneider, P. Ndegwa, V. K. Vaddella, K. Johnson, K. J. Shingfield, and S. K R. Karnati. 2009. Effect of lauric acid and coconut oil on ruminal fermentation, digestion, ammonia losses from manure, and milk fatty acid composition in lactating cows. J. Dairy Sci. 92:55615582 .

Huhtanen, P., S. Ahvenjärvi, G. A. Broderick, S. M. Reynal, and K. J. Shingfield. 2010. Quantifying ruminal digestion of organic matter and neutral detergent fiber using the omasal sampling technique in cattle - A meta-analysis. J. Dairy Sci. 93:3203-3215.

Huhtanen, P., P. G. Brotz, and L. D. Satter. 1997. Omasal sampling technique for assessing fermentative digestion in the forestomach of dairy cows. J. Anim. Sci. 75:1380-1392.

Ipharraguerre, I. R., and J. H. Clark. 2003. Usefulness of ionophores for lactating dairy cows: A review. Anim. Feed Sci. Technol. 106:39-57.

Ipharraguerre, I. R., S. M. Reynal, M. Liñeiro, G. A. Broderick, and J. H. Clark. 2007. A comparison of sampling sites, digesta and microbial markers, and microbial references for assessing the postruminal supply of nutrients in dairy cows. J. Dairy Sci. 90:1904-1919.

Jenkins, T. C., R. J. Wallace, P. J. Moate, and E. E. Mosley. 2008. Board-invited review: Recent advances in biohydrogenation of unsaturated fatty acids within the rumen microbial ecosystem. J. Anim. Sci. 86:397-412.

Karnati, S. K. R., J. T. Sylvester, S. M. Noftsger, Z. Yu, N. R. StPierre, and J. L. Firkins. 2007. Assessment of ruminal bacterial populations and protozoal generation time in cows fed different methionine sources. J. Dairy Sci. 90:798-809.

Krizsan, S. J., S. Ahvenjärvi, H. Volden, and G. A. Broderick. 2010. Estimation of rumen outflow in dairy cows fed grass silage-based diets by use of reticular sampling as an alternative to sampling from the omasal canal. J. Dairy Sci. 93:1138-1147.

Machmüller, A., and M. Kreuzer. 1999. Methane suppression by coconut oil and associated effects on nutrient and energy balance in sheep. Can. J. Anim. Sci. 79:65-72.

Mathew, B., M. L. Eastridge, E. R. Oelker, J. L. Firkins, and S. K. R. Karnati. 2011. Interactions of monensin with dietary fat and carbohydrte components on ruminal fermentation and production responses by dairy cows. J. Dairy Sci. 94:396-409.

Matsumoto, M., T. Kobayashi, A. Takenaka, and H. Itabashi. 1991. Defaunation effects of medium-chain fatty acids and their derivatives on goat rumen protozoa. J. Gen. Appl. Microbiol. 37:439445.

McGuffey, R. K., L. F. Richardson, and J. I. D Wilkinson.. 2001. Ionophores for dairy cattle: Current status and future outlook. J. Dairy Sci. 84(E. Suppl.):E194-E203.

Mertens, D. R. 1997. Creating a system for meeting the fiber requirements of dairy cows. J. Dairy Sci. 80:1463-1481. 
NRC. 2001. Nutrient Requirements of Dairy Cattle. 7th rev. ed. Natl. Acad. Sci., Washington, DC.

Noftsger, S., N. R. St-Pierre, and J. T. Sylvester. 2005. Determination of rumen degradability and ruminal effects of three sources of methionine in lactating cows. J. Dairy Sci. 88:223-237.

Oelker, E. R., C. Reveneau, and J. L. Firkins. 2009. Interaction of molasses and monensin in alfalfa hay- or corn silage-based diets on rumen fermentation, total tract digestibility, and milk production by Holstein cows. J. Dairy Sci. 92:270-285.

Oldick, B. S., and J. L. Firkins. 2000. Effects of degree of fat saturation on fiber digestion and microbial protein synthesis when diets are fed twelve times daily. J. Anim. Sci. 78:2412-2420.

Oldick, B. S., J. L. Firkins, and N. R. St-Pierre. 1999. Estimation of microbial nitrogen flow to the duodenum of cattle based on dry matter intake and diet composition. J. Dairy Sci. 82:1497-1511.

Onetti, S. G., R. D. Shaver, M. A. McGuire, and R. R. Grummer. 2001. Effect of type and level of dietary fat on rumen fermentation and performance of dairy cows fed corn silage-based diets. J. Dairy Sci. 84:2751-2759.

Or-Rashid, M. M., N. E. Odongo, and B. W. McBride. 2007. Fatty acid composition of ruminal bacteria and protozoa, with emphasis on conjugated linoleic acid, vaccenic acid, and odd-chain and branched-chain fatty acids. J. Anim. Sci. 85:1228-1234.

Owens, F. N., and A. L. Goetsch. 1986. Digesta passage and microbial protein synthesis. Pages 196-226 in Control of Digestion and Metabolism in Ruminants. L. P. Milligan, W. L. Grovum, and A. Dobson, ed. Prentice-Hall, Englewood Cliffs, NJ.

Palmquist, D. L., and T. C. Jenkins. 2003. Challenges with fats and fatty acid methods. J. Anim. Sci. 81:3250-3254.

Pantoja, J., J. L. Firkins, M. L. Eastridge, and B. L. Hull. 1994. Effects of fat saturation and source of fiber on site of nutrient digestion and milk production by lactating dairy cows. J. Dairy Sci. 77:2341-2356.

Reveneau, C., C. V. D. M. Ribeiro, M. L. Eastridge, and J. L. Firkins. 2012. Interaction of unsaturated fat or coconut oil with monensin in lactating dairy cows fed 12 times daily. II. Fatty acid flow to the omasum and milk fatty acid profile. J. Dairy Sci. 95:2061-2069. http://dx.doi.org/10.3168/jds.2011-4888.

Ruiz, R., G. L. Albrecht, L. O. Tedeschi, G. Jarvis, J. B. Russell, and D. G. Fox. 2001. Effect of monensin on the performance and nitrogen utilization of lactating dairy cows consuming fresh forage. J. Dairy Sci. 84:1717-1727.

Russell, J. B., and A. J. Houlihan. 2003. Ionophore resistance of ruminal bacteria and its potential impact on human health. FEMS Microbiol. Rev. 27:65-74.
Schelling, G. T. 1984. Monensin mode of action in the rumen. J. Anim. Sci. 58:1518-1527.

Siddons, R. C., J. Paradine, D. E. Beever, and P. R. Cornell. 1985. Ytterbium acetate as a particulate-phase digesta-flow marker. Br. J. Nutr. 54:509-519.

Sutton, J. D., R. Knight, A. B. McAllan, and R. H. Smith. 1983 Digestion and synthesis in the rumen of sheep given diets supplemented with free and protected oils. Br. J. Nutr. 49:419-432.

Sylvester, J. T., S. K. R. Karnati, B. A. Dehority, M. Morrison, G. L. Smith, N. R. St-Pierre, and J. L. Firkins. 2009. Rumen protozoa decrease generation time and adjust $18 \mathrm{~S}$ ribosomal DNA copies to adapt to decreased transfer interval, starvation, and monensin. J. Dairy Sci. 92:256-269.

Towne, G., T. G. Nagaraja, R. T. Brandt Jr., and K. E. Kemp. 1990. Dynamics of ruminal ciliated protozoa in feedlot cattle. Appl. Environ. Microbiol. 56:3174-3178.

Udén, P., P. E. Colucci, and P. J. Van Soest. 1980. Investigation of chromium, cerium and cobalt as markers in digesta. Rate of passage studies. J. Sci. Food Agric. 31:625-632.

Ueda, K. A. Ferlay, J. Chabrot, J. J. Loor, Y. Chilliard, and M. Doreau. 2003. Effect of linseed oil supplementation on ruminal digestion in dairy cows fed diets with different forage:concentrate. J. Dairy Sci. 86:3999-4007.

Weimer, P. J., D. M. Stevenson, D. R. Mertens, and E. E. Thomas 2008. Effect of monensin feeding and withdrawal on populations of individual bacterial species in the rumen of lactating dairy cows fed high-starch diets. Appl. Microbiol. Biotechnol. 80:135-145.

Whitehouse, N. L., V. M. Olson, C. G. Schwab, W. R. Chesbro, K. D. Cunningham, and T. Lykos. 1994. Improved techniques for dissociating particle-associated mixed ruminal microorganisms from ruminal digesta solids. J. Anim. Sci. 72:1335-1343.

Williams, C. H., D. J. David, and O. Iismaa. 1962. The determination of chromic oxide in feces samples by atomic absorption spectrophotometry. J. Agric. Sci. 59:381-385.

Wylie, M. J., W. C. Ellis, J. H. Matis, E. M. Bailey, W. D. James, and D. E. Beever. 2000. The flow of large particles and solutes through segments of the digestive tracts of cattle. Br. J. Nutr. 83:295-306.

Yabuuchi, Y., Y. Matsuchita, H. Otsuka, K. Fukamachi, and Y. Kobayashi. 2006. Effects of supplemental lauric acid-rich oils in high-grain diet on in vitro rumen fermentation. Anim. Sci. J. $77: 300-307$.

Yang, C. M., and J. B. Russell. 1993. The effect of monensin supplementation on ruminal ammonia accumulation in vitro and the numbers of amino acid-fermenting bacteria. J. Anim. Sci. 71:3470-3476. 